\title{
Influence of antiTNF-alpha antibody treatment on fracture healing under chronic inflammation
}

\author{
Melanie Timmen ${ }^{2 *}$, Heriburg Hidding ${ }^{2}$, Britta Wieskötter ${ }^{1}$, Wolfgang Baum³ ${ }^{3}$ Thomas Pap ${ }^{2}$, Michael J Raschke ${ }^{1}$, \\ Georg Schett ${ }^{3}$, Jochen Zwerina ${ }^{4}$ and Richard Stange ${ }^{1,2}$
}

\begin{abstract}
Background: The overexpression of tumor necrosis factor (TNF)-a leads to systemic as well as local loss of bone and cartilage and is also an important regulator during fracture healing. In this study, we investigate how TNF-a inhibition using a targeted monoclonal antibody affects fracture healing in a TNF-a driven animal model of human rheumatoid arthritis (RA) and elucidate the question whether enduring the anti TNF-a therapy after trauma is beneficial or not.

Methods: A standardized femur fracture was applied to wild type and human TNF-a transgenic mice (hTNFtg mice), which develop an RA-like chronic polyarthritis. hTNFtg animals were treated with anti-TNF antibody (Infliximab) during the fracture repair. Untreated animals served as controls. Fracture healing was evaluated after 14 and 28 days of treatment by clinical assessment, biomechanical testing and histomorphometry.

Results: High levels of TNF-a influence fracture healing negatively, lead to reduced cartilage and more soft tissue in the callus as well as decreased biomechanical bone stability. Blocking TNF-a in hTNFtg mice lead to similar biomechanical and histomorphometrical properties as in wild type.

Conclusions: High levels of TNF-a during chronic inflammation have a negative impact on fracture healing. Our data suggest that TNF-a inhibition by an anti-TNF antibody does not interfere with fracture healing.
\end{abstract}

Keywords: Anti-TNFa, Inflammation, Fracture healing, Rheumatoid arthritis, Treatment

\section{Background}

Inflammatory diseases such as rheumatoid arthritis (RA), do not only increase the risk of fractures $[1,2]$ but may also impair fracture healing by delaying the process and leading to non-unions [3]. Tumor necrosis factor alpha (TNF- $\alpha$ ) is one of the main trigger of chronic inflammation in rheumatoid arthritis [4]. TNF- $\alpha$ is also critical for the cause of systemic as well as local loss of bone and cartilage during the course of disease [5]. The use of TNF- $\alpha$ blocking antibodies ameliorates the symptoms of this disease [6]. For instance, treatment with Infliximab, a (chimeric) monoclonal TNF- $\alpha$ antibody, has reduced the symptoms of RA patients [7]. Moreover, TNF-blocking agents combine a strong anti-inflammatory potential leading to direct protection of bone and cartilage [8].

TNF- $\alpha$ is also an important regulator of fracture healing [9]. Aside from Interleukin (IL)-1, -6 and -11 , TNF- $\alpha$ is

\footnotetext{
* Correspondence: Melanie.Timmen@ukmuenster.de

${ }^{2}$ Institute for Experimental Muskuloskeletal Medicine IEMM, University

Hospital Muenster, Muenster, Germany

Full list of author information is available at the end of the article
}

active within the initial inflammatory phase of fracture healing in macrophages and other inflammatory cells, where it leads to neo-angiogenesis and induces osteogenic differentiation of mesenchymal stem cells. In the terminal remodeling phase of fracture healing, high expression of TNF- $\alpha$ and IL-1 activates osteoclasts which degrade the trabecular bone and osteoblasts which regenerate the lamellar bone [10]. Previous studies have demonstrated that lack of TNF- $\alpha$ signaling during fracture healing impairs callus remodeling [11]. Thus, the TNF- $\alpha$ receptor knockout mice show a delay in fracture healing caused by a retarded development of cartilage, followed by chondrocyte apoptosis and remodeling of mineralized cartilage in the late phase of fracture healing [12].

Therefore, TNF- $\alpha$ is an important mediator during different phases of fracture healing. However, the influence of TNF- $\alpha$ blockade, as in treatment of RA patients under chronic inflammatory conditions, is still unknown. A retrospective study of rheumatoid patients treated with TNF- $\alpha$ antagonists showed no decreased risk of fractures 
[13]. Since TNF- $\alpha$ antibody therapy is widely used for treatment of RA and chronic inflammation, the question remains, whether the therapy should be continued in the case of a fracture or should be suspended. Therefore, we investigated the influence of TNF- $\alpha$ inhibition on fracture healing in an established model of chronic murine rheumatoid/inflammatory arthritis.

\section{Methods}

\section{Mice and fracture model}

Generation of heterozygous human tumor necrosis factor transgenic (hTNFtg) mice (strain Tg197) were described previously [14]. Homozygous hTNFtg mice develop a chronic inflammatory arthritis due to the overexpression of human TNF which is acting on the murine TNF receptor I. Disease starts at the age of 6 weeks and is accompanied by local and systemic bone loss reflecting inflammatory bone disease of human rheumatoid arthritis. We used 12 week old, female mice for the fracture experiments. Three groups of 20 mice, including wild type, hTNFtg untreated and hTNFtg treated with a (chimeric) antiTNF- $\alpha$ antibody (Infliximab, $10 \mathrm{mg} / \mathrm{kg}, 3$ times weekly, Centocor, The Netherlands, TNFi) as described [15]. After anaesthesia using a ketamine hydrochloride/xylazine mixture (80 and $12 \mathrm{mg} / \mathrm{kg}$ body weight, i.p.) the left leg was fractured with three point bending. It was stabilized with an intramedullary nail (hollow needle 23G) [16] (see also Figure 1). Carprofen ( $4 \mathrm{mg} / \mathrm{kg}$ intra muscular) was given as an analgesic and further on at 24 hour intervals when required. Mice were euthanized by cervical dislocation 14 or 28 days after surgery. All experiments were performed according to the protocol approved by the Animal Care and Use Committee of the University Hospital Erlangen, Germany.

\section{Biomechanical analyses}

For biomechanical analyses, mice ( $n=10$, each wild type, hTNFtg or hTNFtg treated with Infliximab) were euthanized 28 days after surgery. Both femurs were dissected and prepared for biomechanical testing as described
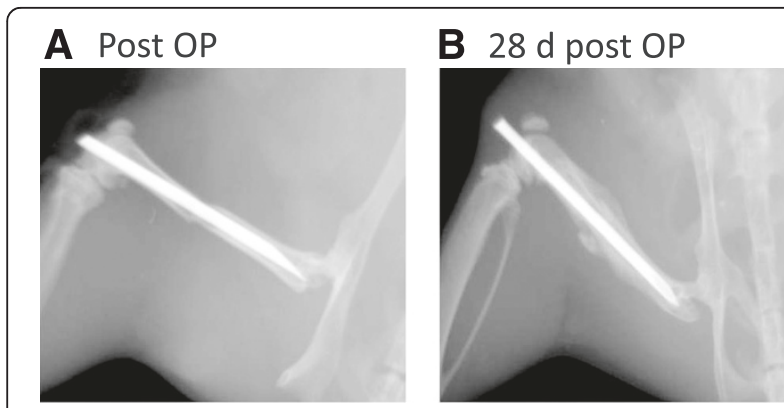

Figure 1 Radiographs of a fractured femur after surgery OP (A) and after $\mathbf{2 8}$ days of healing (B). Mouse femur fractured and stabilized by an intramedullary nail (Schmidmaier et al., [18], modified). previously $[17,18]$. Briefly, the proximal and distal ends of each femur were embedded into two molds with bone cement (Palacos R, Heraeus Kulzer GmbH, Germany). Each mold was then connected to a pivoted axis. A linear constant feed rate, generated by a material testing machine (LR5Kplus, Lloyd Instruments, Meerbusch, Germany), was loaded by a lever attached to one of the pivoted axes. The bone was preloaded at an axial force of $5 \mathrm{~N}$ and a constant linear propulsion $(\mathrm{v}=1 \mathrm{~mm} / \mathrm{min})$ was applied by the testing machine. The translation of the material testing machine was transformed to an uniform torsional movement. The free axis was connected to a strain-gauge $\left(F_{\max }=250 \mathrm{~N}, \mathrm{XLC}\right.$, Lloyd Instruments, Meerbusch, Germany) that detected the torsional force. The data were recorded using Catman32 software (HBM, Darmstadt, Germany) and analyzed by Microsoft Excel (Redmont, USA). The angle of failure and the maximum load were determined as material characteristics and the torsional stiffness $\left(\mathrm{N} /{ }^{\circ}\right)$ was calculated as a biomechanical parameter. Each parameter was compared with the values of the non-fractured contralateral femur (ratio of fractured/non-fractured femur (100\%)). Data shown are medians with a range of up to 8 measurements for each group.

\section{Histomorphometry}

For histomorphological analyses fractured femurs $(n=10$, each group) were embedded undecalcified in methylmethacrylate (Technovit ${ }^{\oplus}$ 9100, Heraeus, Germany). Sagittal serial sections $(5 \mu \mathrm{m})$ were stained with alcian blue. Image Pro Plus software (ImagePro ${ }^{\circ}$ Plus 7.0, Media Cybernetics Inc., Bethesda, USA) was used to determine and calculate the following histological parameters within the area of interest (see also Figure 2A): whole callus area (black line, cartilage area (dotted line)/total callus area and area of soft tissue (dashed line)/total callus area. The histological analysis was performed randomized and blinded with regard to genotype and treatment. Complicated fractures were excluded from the analysis. The data shown are means with SD of up to10 measurements of each group.

\section{Statistic}

Statistical analysis (Mann-Whitney-U-test: conducted between each group, non-parametric, two tailed, Confidence Interval: 95\%) was carried out using GraphPad Prism 5.02 (GraphPad Software, San Diego, USA). p-values >0.05 were regarded as significant, $\mathrm{p}$-values between 0.05 and 0.1 indicate tendency.

\section{Results}

\section{Clinical assessment}

As described previously, the hTNFtg mice are smaller in size and weight compared to their wild type littermates 


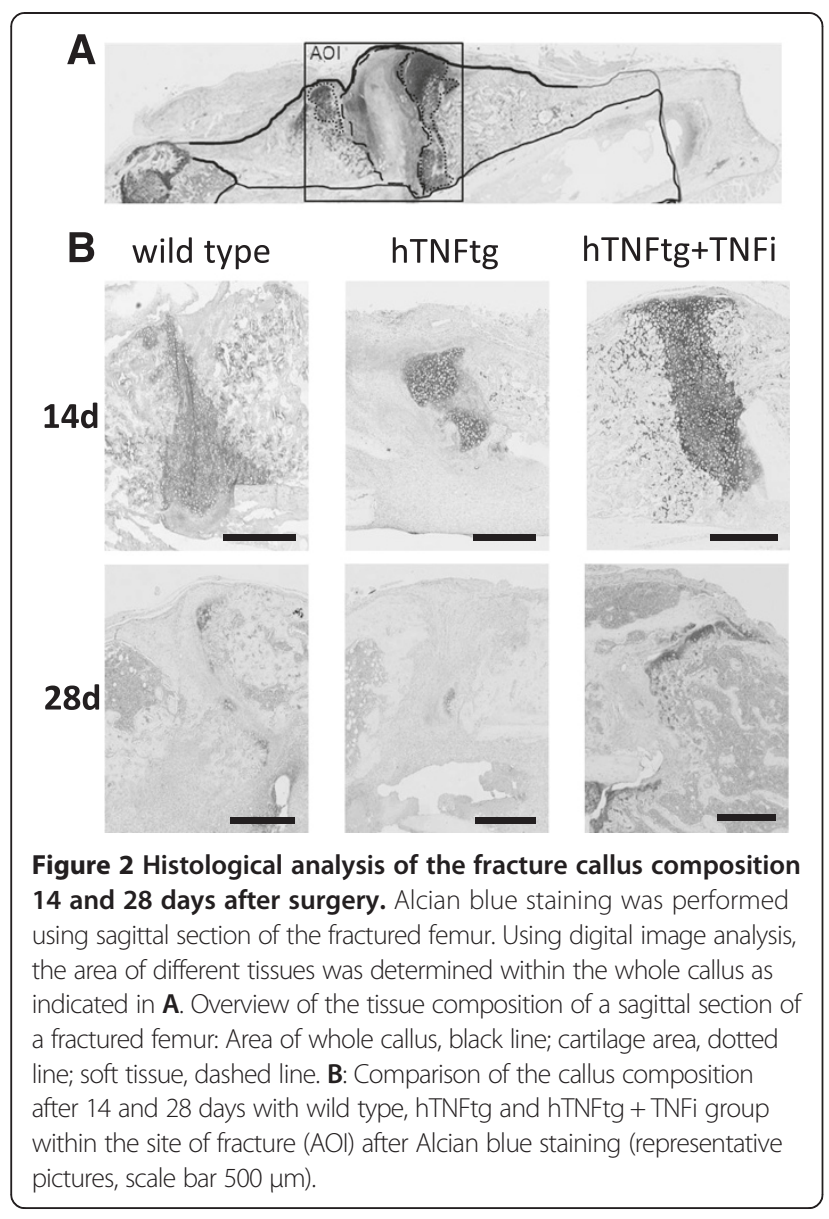

$[14,19]$. A treatment of these mice with a human anti-TNF antibody prevents the development of an inflammatory polyarthritis [14]. In our study, we used hTNFtg mice at the age of 12 weeks for surgery and monitored the follow-up of the healing process for up to 4 weeks. However, the animals were smaller compared to wild type mice. This influenced the outcome of fracturing and therefore the progression of fracture healing. As shown by radiographic and histological pictures, some fractures occurred near the knee joint or were dislocated or fragmentary, and were therefore excluded from further analyses.

\section{Biomechanical bone stability after fracture}

Two different material characteristics were measured, that are influenced by the tissue composition during fracture healing. Firstly, the force that is needed to break the bone, characterized by maximum torque, as well the angle of failure that is used as a parameter of the flexibility of the bone, were measured. Secondly, the torsional stiffness was calculated from these values as a measure for the biomechanical stability of the bone. After 28 days of healing there was no significant difference in the maximum torque between the wild type group and both hTNFtg groups, although the standard deviation was high in the hTNFtg group without treatment (Figure 3). The fractured femur yield almost $100 \%$ of the maximum torque measured for the unfractured femur in all groups (wild type: 89\%, hTNFtg: 99.5\%, hTNFtg + TNFi: 69\%). Interestingly, the angle of failure in the wild type group (128\%) was comparable to the hTNFtg + TNFi group (98\%), but significantly increased in the hTNFtg group (221\%, wild type vs. hTNFtg: $\mathrm{p}=0.0293$; hTNFtg vs. hTNFtg + TNFi: $\mathrm{p}=0.014)$. The torsional stiffness, however, was not significantly altered in the hTNFtg group (69.3\%) compared to both wild type (91.3\%) and the TNFi treated hTNFtg group (96\%) (wild type vs. hTNFtg: $\mathrm{p}=0.345 ;$ hTNFtg vs hTNFtg + TNFi: $\mathrm{p}=0.617$ ).

\section{Histomorphological analysis of fracture callus composition after 14 and 28 days of healing}

Further investigation of the callus tissue composition provided an indication for the altered biomechanical properties of the three different groups. Sagittal sections of femurs were stained for cartilage using alcian blue staining and for determination of the whole callus area (Figure 2A). The area of cartilage (stained in blue; dotted line) and the area of soft tissue (dashed line) were compared in the callus area. These parameters change the

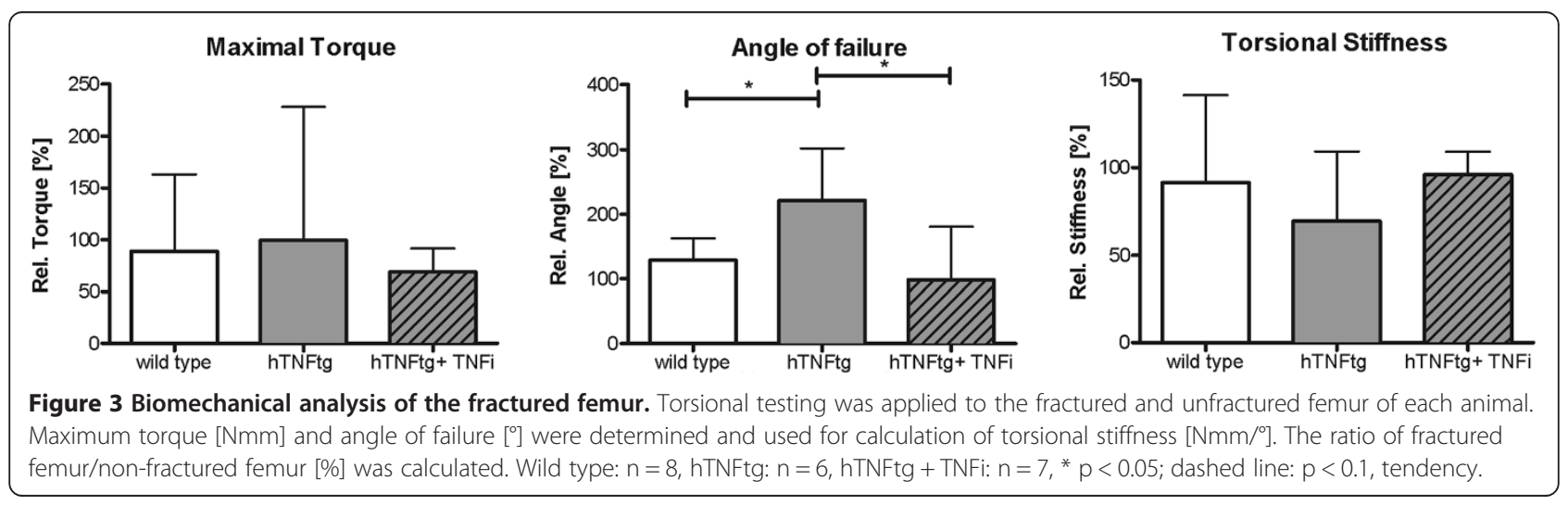


most within the investigated time points at day 14 and day 28 (Figure 2). The quantitative analysis of all fracture calli showed a significantly bigger callus area in the hTNFtg and hTNFtg + TNFi treated groups compared to the wild type group after 14 days (37\%, Figure $4 \mathrm{~A}$ ) and 28 days (30\%, Figure 4D). Further investigation of the composition surrounding the fracture site revealed an increased area of soft tissue in the hTNFtg group $(24.1 \%$ vs. $11.4 \%$ (wild type, $\mathrm{p}=0.0307)$ and $18.7 \%$ (hTNFtg + TNFi) compared to the wild type at day 14 (Figure 4B). Additionally, the hTNFtg + TNFi group displayed twice as much cartilage than both other groups on day $14(18.4 \%$ vs $9.9 \%$ in wild type $(\mathrm{p}=0.0234)$ or $7.6 \%$ in hTNFtg $(\mathrm{p}=0.0159)$ (Figure $4 \mathrm{C})$. After 28 days the content of soft tissue was higher within the wild type group (5.8\% vs. $2.5 \%$ in wild type and $2 \%$ in hTNFtg + TNFi; p $<0.1)$. The amount of cartilage in wild type and hTNFtg + TNFi group was lower $(0.8 \%)$ compared to 14 days, but much less in hTNFtg without treatment $(0.18 \%)$ (Figure 4B). Furthermore, the area of mineralized bone (trabecular bone within the callus area) was determined, but there were no differences within the three groups (Data not shown).

\section{Discussion}

The hTNFtg mouse is considered to be a valuable model of human RA $[19,20]$. In these animals, overexpression of human TNF- $\alpha$ induces severe inflammatory polyarthritis. This arthritis shares many hallmarks with the human counterpart, such as polyarticular involvement of the small joints, chronic and progressive course of disease, and the destruction of cartilage and subchondral bone. The disease is driven by the overexpression of proinflammatory cytokines. The overexpression of TNF- $\alpha$ was described as being responsible for a dramatic loss of trabecular bone and, to a lesser extent, cortical bone [20]. The influence of a chronic inflammation on fracture healing, however, has not been studied. Therefore, we used hTNFtg animals, with high systemic levels of TNF- $\alpha$ to investigate its influence on the composition of the fracture callus and the progression of the healing process.

The importance of TNF- $\alpha$ signaling during fracture healing is commonly accepted today. On the one hand, it is known that TNF- $\alpha$ expression increases soon after injury $[11,21]$. During this inflammatory phase different cell types, including mesenchymal stem cells, located in the surrounding tissue, are recruited to the fracture site and initiate the formation of the primary callus. Different studies were able to demonstrate that deficiency of TNF- $\alpha$ signaling causes a delay in callus remodeling with regard to chondrocyte maturation and apoptosis in the later phases of fracture healing $[11,12,22]$. On the other hand, high levels of TNF- $\alpha$ contribute to accelerated loss of cartilage during fracture healing as seen in diabetic mice [23]. In our study we have demonstrated that high systemic levels of TNF- $\alpha$ influence the biomechanical stability and composition of the bone in the course of fracture healing, lead to increased callus formation with less cartilage and more soft tissue within the fracture gap. These alterations of the callus composition resulted in lowered biomechanical stability with a higher flexibility of bone within the callus after 28 days of healing.

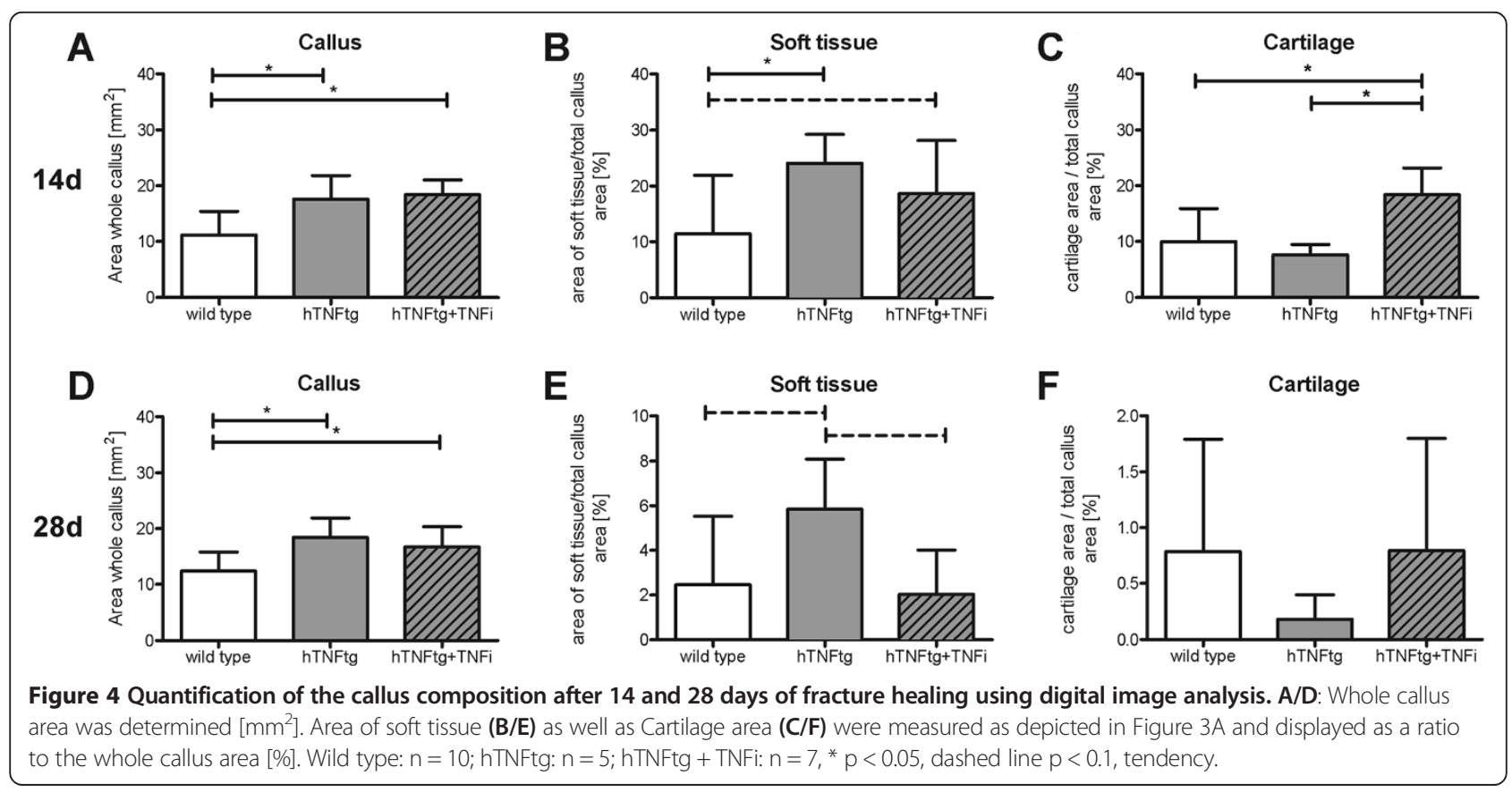


Histologically, we found that the callus of hTNFtg animals was built of less cartilage and more soft tissue compared to the wild type which leads to an altered stability of the callus. Therefore, our results indicate a negative influence of chronically elevated TNF- $\alpha$ level during the fracture healing process.

TNF- $\alpha$-inhibitors like Infliximab are used in treatment of rheumatic patients to bind TNF- $\alpha$ with high affinity to reduce inflammatory symptoms [6,24]. The high efficiency of the blocking hTNF antibody was proven within the hTNFtg animal model [14]. Treated animals do not show any signs of rheumatoid like disease. The influence of a TNF- $\alpha$-inhibitor on fracture healing, however, has been investigated in a wild type rat model under noninflammatory conditions. In this case the authors did not find any impairment of metaphysal bone healing [25]. Under chronic inflammatory conditions, as it was shown in this study, the blockade of TNF- $\alpha$ during fracture healing (by Infliximab treatment) led to an increased callus size, which was accompanied by an increase in cartilage tissue compared to the not treated group. After 28 days of fracture healing, the fracture callus composition resembled the wild type situation. Biomechanical testing revealed no differences compared to wild type fracture healing. Treatment with Infliximab even seemed to compensate the derogating effects of elevated systemic TNF- $\alpha$ levels on fracture healing which can be concluded from the similarity of the biomechanical and histological results of the TNFi treated group compared to wild type in our model. It might be interesting to further distinguish between the negative effects of pathologically elevated levels of TNF- $\alpha$ and the positive effects of endogenous TNF signaling during fracture healing. This could be done by performing studies using the fracture model and dose dependent treatment with hTNF blocking antibody and to look for the onset of callus development and callus composition in the course of healing. Our results provide indication that rheumatoid arthritis patients, who sustained a fracture during the treatment with TNF- $\alpha$ antagonist, should continue this therapy.

\section{Conclusion}

Elevated TNF- $\alpha$ level have a negative impact on the physiological development of the callus and thereby impair fracture healing in this murine model of chronic inflammation. We have found that the treatment of this chronic inflammation during fracture healing is beneficial and restores the biomechanical and morphological condition as found in the wild type. Further studies on fracture healing under chronic inflammatory conditions in animal models and rheumatoid arthritis patients will be necessary to further elucidate the mechanisms of this positive effect of anti-TNF $\alpha$-treatment.

\section{Abbreviations}

TNF-a: Tumor necrosis factor alpha; RA: Rheumatoid arthritis; hTNFtg: Mice with a human TNF alpha transgenic background; IL: Interleukin; TNFi: AntiTNFalpha antibody treatment; MSC: Mesenchymal stem cell; AOI: Area of interest.

\section{Competing interests}

The authors declare that they have no competing interests.

\section{Authors' contributions}

MT, WB, HH, BW and RS collected the data. RS, TP and JZ designed the study. TP, MR and GS contributed to the data analysis and interpretation. MT, RS and JZ wrote the manuscript. All authors read and approved the final manuscript.

\section{Acknowledgements}

We thank Simone Niehues and Iska Leifert for excellent technical assistance. We acknowledge support by Deutsche Forschungsgemeinschaft and Open Access Publication Fund of University of Muenster.

\section{Funding}

This project was funded by the ELAN Fonds of the University of ErlangenNuremberg (J.Z.).

\section{Author details}

${ }^{1}$ Department of Trauma, Hand and Reconstructive Surgery, University Hospital Muenster, Muenster, Germany. ${ }^{2}$ Institute for Experimental Muskuloskeletal Medicine IEMM, University Hospital Muenster, Muenster, Germany. ${ }^{3}$ Department of Internal Medicine 3, Rheumatology and Clinical Immunology, University of Erlangen-Nuremberg, Erlangen, Germany. ${ }^{4}$ Ludwig Boltzmann Institute of Osteology at the Hanusch Hospital of WGKK and AUVA Trauma Centre Meidling, 1st Medical Department, Hanusch Hospital, Vienna, Austria.

Received: 27 February 2014 Accepted: 16 May 2014

Published: 29 May 2014

\section{References}

1. Abdulghani S, Caetano-Lopes J, Canhao H, Fonseca JE: Biomechanical effects of inflammatory diseases on bone-rheumatoid arthritis as a paradigm. Autoimmun Rev 2009, 8(8):668-671.

2. Bogoch ER, Moran E: Abnormal bone remodelling in inflammatory arthritis. Can J Surg 1998, 41(4):264-271.

3. Claes $L$, Recknagel $S$, Ignatius $A$ : Fracture healing under healthy and inflammatory conditions. Nat Rev Rheumatol 2012, 8(3):133-143.

4. Mclnnes IB, Schett $G$ : The pathogenesis of rheumatoid arthritis. N Engl J Med 2011, 365(23):2205-2219.

5. Schett G: Effects of inflammatory and anti-inflammatory cytokines on the bone. Eur J Clin Invest 2011, 41(12):1361-1366.

6. Tracey D, Klareskog L, Sasso EH, Salfeld JG, Tak PP: Tumor necrosis factor antagonist mechanisms of action: a comprehensive review. Pharmacol Ther 2008, 117(2):244-279.

7. Elliott MJ, Maini RN, Feldmann M, Kalden JR, Antoni C, Smolen JS, Leeb B, Breedveld FC, Macfarlane JD, Bijl H, Woody JN: Randomised double-blind comparison of chimeric monoclonal antibody to tumour necrosis factor alpha (cA2) versus placebo in rheumatoid arthritis. Lancet 1994, 344(8930):1105-1110.

8. Schett G, Coates LC, Ash ZR, Finzel S, Conaghan PG: Structural damage in rheumatoid arthritis, psoriatic arthritis, and ankylosing spondylitis: traditional views, novel insights gained from TNF blockade, and concepts for the future. Arthritis Res Ther 2011, 13(Suppl 1):S4.

9. Kon T, Cho TJ, Aizawa T, Yamazaki M, Nooh N, Graves D, Gerstenfeld LC, Einhorn TA: Expression of osteoprotegerin, receptor activator of NF-kappaB ligand (osteoprotegerin ligand) and related proinflammatory cytokines during fracture healing. J Bone Miner Res 2001, 16(6):1004-1014.

10. Marsell R, Einhorn TA: The biology of fracture healing. Injury 2011, 42(6):551-555.

11. Gerstenfeld LC, Cho TJ, Kon T, Aizawa T, Cruceta J, Graves BD, Einhorn TA: Impaired intramembranous bone formation during bone repair in the absence of tumor necrosis factor-alpha signaling. Cells Tissues Organs 2001, 169(3):285-294.

12. Gerstenfeld LC, Cho TJ, Kon T, Aizawa T, Tsay A, Fitch J, Barnes GL, Graves DT, Einhorn TA: Impaired fracture healing in the absence of TNF-alpha signaling: 
the role of TNF-alpha in endochondral cartilage resorption. $J$ Bone Miner Res 2003, 18(9):1584-1592.

13. Kawai VK, Grijalva CG, Arbogast PG, Curtis JR, Solomon DH, Delzell E, Chen L, Ouellet-Hellstrom R, Herrinton L, Liu L, Mitchell EF Jr, Stein CM, Griffin MR: Initiation of tumor necrosis factor alpha antagonists and risk of fractures in patients with selected rheumatic and autoimmune diseases. Arthritis Care Res (Hoboken) 2013, 65(7):1085-1094.

14. Keffer J, Probert L, Cazlaris H, Georgopoulos S, Kaslaris E, Kioussis D, Kollias G: Transgenic mice expressing human tumour necrosis factor: a predictive genetic model of arthritis. EMBO J 1991, 10(13):4025-4031.

15. Zwerina J, Hayer S, Tohidast-Akrad M, Bergmeister H, Redlich K, Feige U, Dunstan C, Kollias G, Steiner G, Smolen J, Schett G: Single and combined inhibition of tumor necrosis factor, interleukin-1, and RANKL pathways in tumor necrosis factor-induced arthritis: effects on synovial inflammation, bone erosion, and cartilage destruction. Arthritis Rheum 2004, 50(1):277-290.

16. Bertrand J, Stange R, Hidding H, Echtermeyer F, Nalesso G, Godmann L, Timmen M, Bruckner P, Dell'Accio F, Raschke MJ, Pap T, Dreier R: Syndecan 4 supports bone fracture repair, but not fetal skeletal development, in mice. Arthritis Rheum 2013, 65(3):743-752.

17. Stange R, Kronenberg D, Timmen M, Everding J, Hidding H, Eckes B, Hansen U, Holtkamp M, Karst U, Pap T, Raschke MJ: Age-related bone deterioration is diminished by disrupted collagen sensing in integrin alpha2beta 1 deficient mice. Bone 2013, 56(1):48-54.

18. Schmidmaier G, Wildemann B, Cromme F, Kandziora F, Haas NP, Raschke M: Bone morphogenetic protein-2 coating of titanium implants increases biomechanical strength and accelerates bone remodeling in fracture treatment: a biomechanical and histological study in rats. Bone 2002, 30(6):816-822.

19. Li P, Schwarz EM: The TNF-alpha transgenic mouse model of inflammatory arthritis. Springer Semin Immunopathol 2003, 25(1):19-33.

20. Schett G, Redlich K, Hayer S, Zwerina J, Bolon B, Dunstan C, Gortz B, Schulz A, Bergmeister H, Kollias G, Steiner G, Smolen JS: Osteoprotegerin protects against generalized bone loss in tumor necrosis factor-transgenic mice. Arthritis Rheum 2003, 48(7):2042-2051.

21. Feghali CA, Wright TM: Cytokines in acute and chronic inflammation. Front Biosci 1997, 2:d12-d26.

22. Lehmann W, Edgar CM, Wang K, Cho TJ, Barnes GL, Kakar S, Graves DT, Rueger JM, Gerstenfeld LC, Einhorn TA: Tumor necrosis factor alpha (TNF-alpha) coordinately regulates the expression of specific matrix metalloproteinases (MMPS) and angiogenic factors during fracture healing. Bone 2005, 36(2):300-310.

23. Alblowi J, Kayal RA, Siqueira M, McKenzie E, Krothapalli N, McLean J, Conn J, Nikolajczyk B, Einhorn TA, Gerstenfeld L, Graves DT: High levels of tumor necrosis factor-alpha contribute to accelerated loss of cartilage in diabetic fracture healing. Am J Pathol 2009, 175(4):1574-1585.

24. Feldmann M, Brennan FM, Elliott M, Katsikis P, Maini RN: TNF alpha as a therapeutic target in rheumatoid arthritis. Circ Shock 1994, 43(4):179-184

25. Sandberg O, Eliasson P, Andersson T, Agholme F, Aspenberg P: Etanercept does not impair healing in rat models of tendon or metaphyseal bone injury. Acta Orthop 2012, 83(3):305-310.

doi:10.1186/1471-2474-15-184

Cite this article as: Timmen et al:: Influence of antiTNF-alpha antibody treatment on fracture healing under chronic inflammation. BMC

Musculoskeletal Disorders 2014 15:184.

\section{Submit your next manuscript to BioMed Central and take full advantage of:}

- Convenient online submission

- Thorough peer review

- No space constraints or color figure charges

- Immediate publication on acceptance

- Inclusion in PubMed, CAS, Scopus and Google Scholar

- Research which is freely available for redistribution 